\title{
Kjønnsforskjeller i overgang fra langtidssykmelding til uførepensjon i 1997-2002
}

\author{
Sturla Gjesdal \\ Institutt for samfunnsmedisinske fag, Universitetet i Bergen, Kalfarveien 31, 5018 Bergen \\ E-post: sturla.gjesdal@isf.uib.no Telefon:+4755586150 Telefax:+4755586130
}

\begin{abstract}
SAMMENDRAG
Bakgrunn: Denne studien undersøker overgangen fra langtidssykmelding til uførepensjonering for å se om man her kan finne noe av forklaringen på den observerte overhyppighet av uførepensjonering blant kvinner. Metode og materiale: Prospektiv nasjonal kohortstudie som inkluderer 66083 kvinner og 47073 menn i alderen 16-62 år som var sykmeldt lenger enn åtte uker i 1997. Data er hentet fra FD-trygd. Kvinner som var sykmeldt med en W-diagnose (svangerskapsrelatert) ble ekskludert fra analysen pga alder og lav uførefrekvens. Kohorten ble fulgt opp i fem år med overgang til uførepensjon som endepunkt. Betydning av kjønn ble estimert ved hjelp av Cox' proporsjonal hasards analyse, kontrollert for sosiodemografiske faktorer. Vi gjorde separate analyser for de sykmeldte med muskel- og skjelettdiagnoser, psykiske diagnoser, hjerte/lungediagnoser og "andre" sykmeldingsdiagnoser, også med stratifisering for bostedsfylke.

Resultater: $22 \%$ av de sykmeldte mennene og $24 \%$ av kvinnene var uførepensjonert etter fem års oppfølging. Etter justering for sosiodemografiske faktorer var risiko for uførepensjon fortsatt høyere for kvinner med muskel- og skjelettdiagnoser, men høyere for menn i de andre diagnosegruppene og totalt.

Konklusjon: Risiko for uførepensjon blant langtidssykmeldte kvinner er ikke høyere enn hos langtidssykmeldte menn. Tvert imot, etter korreksjon for sosiodemografiske variabler, er det langtidssykmeldte menn som har størst risiko for å bli uførepensjonert, særlig innen gruppen som var sykmeldt for en psykisk lidelse. Siden langtidssykefraværet er høyere blant kvinner enn blant menn, er likevel totaleffekten en større uføretilgang blant kvinnelige langtidssykmeldte.
\end{abstract}

\section{Gjesdal S. Gender differences in transition from long-term sickness absence to permanent disability pension, 1997-2002. Nor J Epidemiol 2009; 19 (2): 193-202.}

\section{ENGLISH SUMMARY}

Background: The study investigates the transition from long-term sickness absence to permanent disability pension (DP) in Norway. The aim is to assess whether gender differences in this process explain the observed female excess in disability pensioning in Norway.

Methods and data: Prospective national cohort study including 66,083 women and 47,073 men aged 16-62 years, with a spell of sick leave longer than 8 weeks in 1997. The data is obtained from a national research database (FD-trygd). Women on sick leave with a pregnancy related diagnosis were excluded. The endpoint was granting of a DP. The effect of gender on the risk of obtaining a DP was estimated by means of Cox' proportional hazards analysis, adjusted for sociodemographic factors. Separate analyses were carried out for those with diagnoses indicating diseases in the musculoskeletal, mental, and cardiovascular and respiratory groups combined. Stratified analyses for county of residence were also performed.

Results: $22 \%$ of the male and $24 \%$ of the female sample obtained a DP during follow-up. Adjusted for sociodemographic factors the risk of DP was still higher for women with musculoskeletal diagnoses, but higher for men in the remaining diagnostic groups and overall.

Conclusion: The risk of DP after sickness absence is not higher in women compared to men. On the contrary, after adjustment for relevant sociodemographic variables, men on sick-leave have the highest risk of a future DP. This is most evident among those on sick-leave with a mental diagnosis. However, since longterm sickness absence is much more frequent among women, the total effect is a higher rate of DP among Norwegian women.

\section{INTRODUKSJON}

Det har vært en betydelig tilgang til uførepensjonsordningen etter at myndighetene forlot forsøkene på innstramninger i første halvdel av 1990-tallet (1-4). Samtidig med økende tilgang har kjønnsforskjellene også blitt styrket, og per 31.12 .07 var $58 \%$ av landets uførepensjonister kvinner. Imidlertid mottar $24 \%$ av kvinnene gradert pensjon sammenliknet $15 \%$ av mennene, og kvinner har generelt lavere pensjoner på grunn av lav inntekt som yrkesaktive og gjennomsnittlig færre år i arbeid (4).

Ethvert medlem av Folketrygden som blir varig arbeidsufør etter tre års medlemskap har rett til uførepensjon. Det er ikke noe krav om deltakelse i arbeidslivet for å bli uførepensjonert, men den vanligste inn- 
gangsporten til uførepensjonering er likevel langtidssykmelding til maksimal ytelse ved 52 uker. Ved fortsatt arbeidsuførhet etter dette kan man motta andre ytelser fra Folketrygden, rehabiliteringspenger under medisinsk behandling eller yrkesrettet attføring. Bedre oppfølging av langtidssykmeldte og dermed redusert tilgang til uførepensjonsordningen er ett av hovedmålene i Det inkluderende arbeidsliv, men har hatt mindre oppmerksomhet enn selve sykefraværet (6).

Tiltak rettet mot de som allerede er blitt syke og sykmeldt, sekundcer profylakse, har i dag stor oppmerksomhet innen trygdeforskning. I en rekke land foregår det arbeid for å identifisere utstøtingsmekanismer og prediktorer for at langtidssykmeldte forblir arbeidsufør eller at de gjenvinner arbeidsevnen og returnerer til arbeidslivet, Return To Work eller RTW studies (7-14). Slik forskning gjøres spesielt innen gruppen med muskel- og skjelettproblemer (MSP), fordi dette affiserer en stor del av befolkningen og deres livskvalitet, og utgjør hovedårsaken til sykefravær og økningen i antall uføre (4,15-19). Prediktorer for varig arbeidsuførhet er økende alder, sykefraværsdiagnose og sosioøkonomiske faktorer som lav utdanning og lav inntekt $(6,8,20-23)$.

MSP bidrar sterkt til de observerte kjønnsforskjellene i trygdeforbruk. I perioden 1994-2003 ble 150374 kvinner og 129612 menn innvilget uførepensjon i Norge. $41 \%$ av disse kvinnene og $28 \%$ av mennene ble uførepensjonert på grunn av MSP. Tilgangen til uførepensjon forårsaket av andre lidelser var omtrent lik mellom kjønnene. Figur 1 viser årlig tilgang til uførepensjonering etter kjønn og de viktigste diagnosegrup- pene (4). Sykefravær pga MSP er betydelig høyere for kvinner enn for menn (4,24-26), noe som samsvarer med funn fra epidemiologiske undersøkelser, stort sett surveys, som er gjort både i og utenfor arbeidsstokken, i Norge og andre land med tilsvarende trygdeordninger $(27,28)$. Det er noen få studier som ikke har funnet kjønnsforskjell i sykefraværet (29).

De fleste prospektive studier relatert til MSP har funnet at tendensen til kronifisering, for eksempel målt med sykefraværets varighet og overgangsraten til uførepensjon, er høyere blant kvinner, men studiene har ikke alltid korrigert fullt ut for relevante faktorer (16-19). Vi kjenner få studier som har undersøkt mulige kjønnsforskjeller i kronifiseringprosessen spesifikt (30-31).

Litteraturen vedrørende kvinnelig overhyppighet av MSP, inneholder ulike forklaringer, med varierende grad av forskningsmessig støtte (32) ofte inndelt i:

- Eksponeringsteorien går ut på at kvinner er mer utsatt for uheldige arbeidsforhold og andre patogene faktorer enn menn (33).

- Sårbarhetsteorien impliserer at kvinner tåler mindre skadelige påvirkninger enn menn (34).

- Det finnes også biologiske teorier vedrørende smerteopplevelse og ulik oppbygning av muskel- og skjelettapparatet (35-36). Dette kan forklare økt sårbarhet og høy prevalens av noen spesifikke sykdommer blant kvinner, som osteoporose og fibromyalgi.

- Kvinner har generelt en lavere posisjon i hierarkiet $\mathrm{i}$ arbeidslivet og tjener mindre enn menn. Kjønnsforskjellene i MSP kan "elimineres" når man kontrollerer for slike sosioøkonomiske faktorer $(30,37)$.

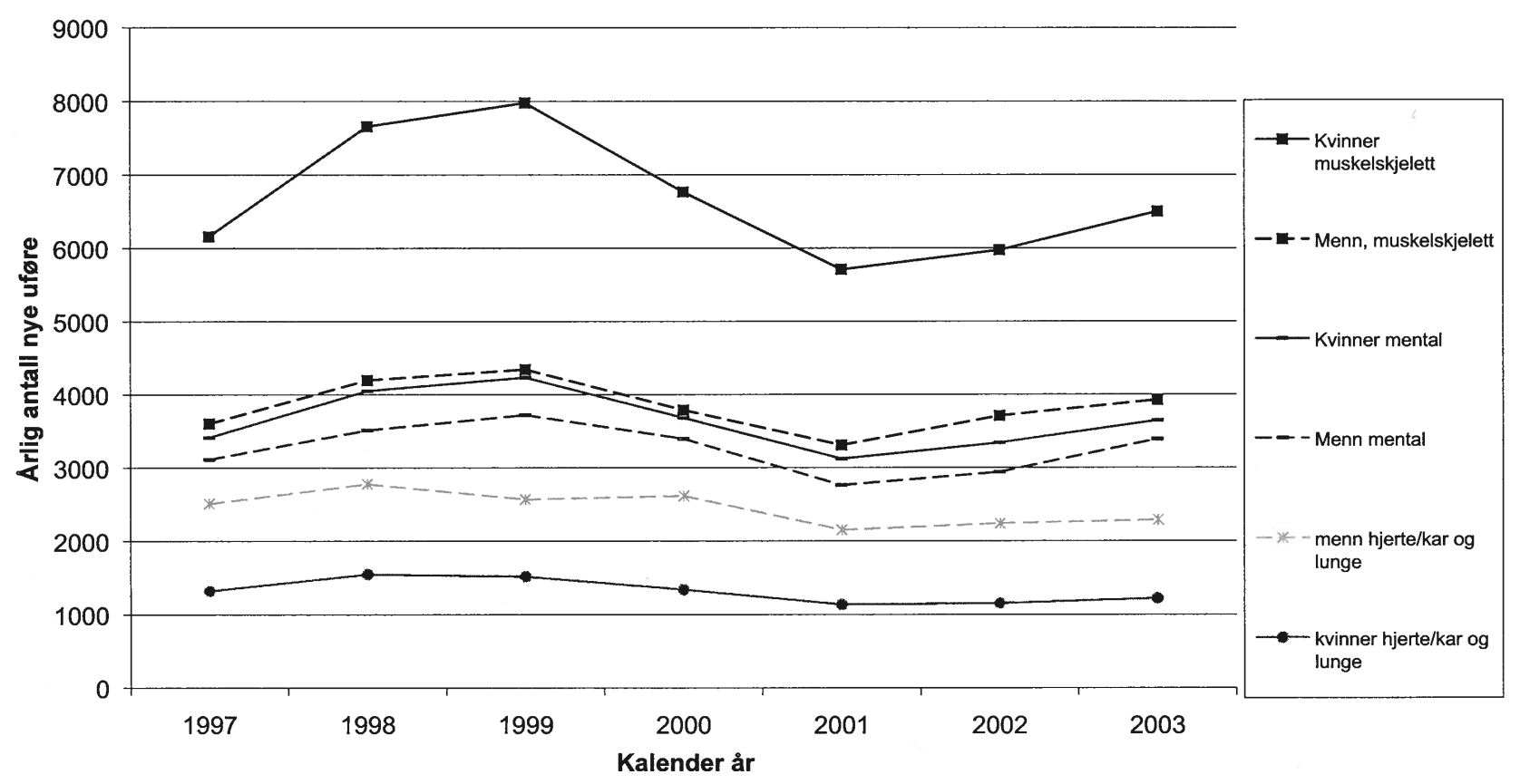

Figur 1. Nye uførepensjonister i 1997-2003, fordelt på viktige diagnosegrupper og kjønn (Kilde: Trygdestatistiske årbøker nav.no). 
- Det er også påvist kjønnsforskjeller i hjelpesøkning (38), i somatisk/psykisk komorbiditet $(39,40)$ og i samvirket mellom smerte og depresjon (40). Depresjon og angst er vanligst blant kvinner (41), og svært vanlig blant mennesker med MSP (39).

- Dobbelbyrde-teorien vektlegger at kvinner blir syke på grunn av påkjenninger både i arbeidslivet og hjemme. Empiriske funn fra Norge har ikke bekreftet dette, men dobbeltbyrdeproblematikken kan variere, for eksempel med grad av likestilling (42-45).

En rekke studier viser at personer med psykiske plager har økt risiko for sykefravær og arbeidsuførhet, og at psykiske plager kan være underdiagnostisert (46-49). I tillegg nedsetter psykiske problemer arbeidsevnen ved andre sykdommer $(38,39)$. Høyere forekomst av "vanlige psykiske lidelser" (50-52) forklarer at kvinner også har høyere forekomst av sykefravær med psykiatriske diagnoser. Dette er påvist både i Norge og Sverige. Menn med psykiske lidelser er imidlertid lenger sykmeldt enn tilsvarende kvinner $(53,54)$, og har høyere risiko for kronifisering og uførepensjonering $(47,55)$ også etter justering for andre relevante faktorer. Dette kan blant annet skyldes en høyere forekomst av rusrelatert komorbiditet, dype depresjoner og andre alvorlige psykiske lidelser hos menn enn hos kvinner.

Denne kohortstudien undersøker mulige kjønnsforskjeller i overgangen fra langtidssykmelding til permanent uførhet i perioden 1997-2002. Siden både sykefravær og kronifiseringsrater varierer mellom fylkene, blir mulige geografiske forskjeller også analysert (5561).

\section{Materiale OG Metode}

\section{Design}

Prospektiv befolkningsundersøkelse basert på registerdata fra FD-trygd.

\section{Risikopopulasjon, inklusjonskriterier og deltakere $\boldsymbol{i}$ studien}

1. januar 1997 var 1019216 menn og 920139 kvinner i alderen 16-62 år yrkesaktive med rett til sykepenger. Alle personer med en sykmeldingsperiode med varighet mer enn åtte uker som ble avsluttet i 1997, ble inkludert i studien. Ved flere enn én sykmelding ble den første benyttet. Dette utgjorde i alt 77126 kvinner og 47563 menn. Dette tilsvarer en årlig (kumulativ) insidens av langtidssykmelding på 4,7/100 for yrkesaktive menn og 8,4/100 for kvinner. 747 kvinner og 490 menn hadde manglende data for utdanning eller inntekt, og ble ikke tatt med i analysene.

I 1997 måtte legene utarbeide en Sykmeldingsattest II ved 8 ukers fravær som inkluderte en sykmeldingsdiagnose basert på ICPC (International Classification of Primary Care). Majoriteten av sykmeldingene i Norge er utskrevet av allmennleger, og ICPC har blitt brukt av trygdeetaten siden 1990 (62), og egner seg derfor til forskningsformål (63). ICPC er organisert i kapitler basert på organsystemer eller patofysiologi. Vi delte diagnosene opp i følgende hovedgrupper: MSP (kapittel L i ICPC), som utgjorde $50 \%$ av langtidssykmeldingene hos kvinner og 54\% hos mennene, psykisk (kapittel P), hjerte/lunger (kapitlene K og R) og alle andre diagnoser $\mathrm{i}$ en gruppe. 10296 av kvinnene $(14,1 \%)$ var sykmeldt med en svangerskapsrelatert diagnose (kapittel W i ICPC). Siden dette er en gruppe med en atypisk alderssammensetning og svært liten risiko for uførpensjonering (1\%) ble disse ekskludert fra analysene, som dermed inkluderte 66083 kvinner og 47073 menn. I dette utvalget hadde 57\% av kvinnene en muskel- og skjelettdiagnose.

\section{Sykefravar og uforepensjon}

Bare yrkesaktive medlemmer i Folketrygden, registrerte arbeidstakere, arbeidsledige og selvstendig næringsdrivende er dekket av sykelønnsordningen. En sykmeldingsattest fra lege er påkrevet etter tre dagers fravær. I 1997 måtte sykmeldende lege utarbeide en spesiell sykeattest som inneholdt en diagnose og plan for videre behandling. Åtte ukers fravær blir derfor ansett som grensen mot langtidssykefravær. Personer i alderen 18-66 år (med lovlig opphold i landet) har rett på uførepensjon ved varig arbeidsuførhet større enn 50\%, etter nærmere kriterier. Uførepensjonsordningen er derfor like tilgjengelig for begge kjønn, selv om yrkesaktiviteten er lavere for kvinner. Også de som ikke har vært $\mathrm{i}$ arbeid kan tilkjennes uførepensjon, men den vanligste inngangsporten er en prosess som starter med ett års sykefravær.

\section{Oppfolging og endepunkt}

Studiekohorten ble fulgt opp fra starten av inklusjonsperioden til 31. desember 2002, eller til sensurering ved død eller emigrasjon. Maksimal og gjennomsnittlig oppfølgingsperiode for hele kohorten var henholdsvis 83 and 61 måneder. Endepunktet var dato for tilkjent uførepensjon basert på uføreregisteret, som er komplett siden det er basis for pensjonsutbetalingene.

\section{Forklaringsvariabler}

Disse ble hentet fra offentlige registre som er koblet via personnummer. Anonymiserte data ble utlevert fra forskningsdatabasen FD-trygd opprettet av Statistisk Sentralbyrå og RTV (NAV). I tillegg til diagnose ble alder, kjønn, årlig inntekt, utdanningsnivå (år), ukentlig arbeidstid, og om man bodde sammen med barn under 18 år, inkludert som uavhengige variabler. Fordeling på ICPC-kapitler og prosentvis overgang til uførepensjon er vist $i$ tabell 1.

\section{Statistiske analyser}

Vi brukte overlevelsesanalyse ved hjelp av Cox' proportional hazards metode (64). Diagnosegrupper og 
Tabell 1. Langtidssykmeldte i Norge (fravær lengre enn 8 uker) i 1997 ( $\mathrm{N} \mathrm{og} \%$ ), og andel av disse ( $\mathrm{N}$ og \%) som fikk uførepensjon (UFP) i perioden fram til 31.12.2002, fordelt på diagnosekapitler og kjønn.

\begin{tabular}{|c|c|c|c|c|c|c|c|c|}
\hline \multirow[b]{2}{*}{ Diagnosegrupper } & \multicolumn{4}{|c|}{ Menn } & \multicolumn{4}{|c|}{ Kvinner } \\
\hline & $\mathrm{N}$ & $\%$ & Overgang til UFP & $\%$ & $\mathrm{~N}$ & $\%$ & Overgang til UFP & $\%$ \\
\hline Muskel- og skjelett & 26307 & 56 & 4602 & 17 & 37942 & 50 & 8409 & 22 \\
\hline Psykisk & 7099 & 15 & 1819 & 26 & 12383 & 16 & 2902 & 23 \\
\hline Hjerte/kar & 3913 & 8 & 1538 & 39 & 1952 & 3 & 744 & 38 \\
\hline Luftveier/lunger & 1335 & 3 & 398 & 30 & 1793 & 2 & 547 & 31 \\
\hline Nervesystem & 2051 & 4 & 722 & 35 & 2739 & 4 & 897 & 33 \\
\hline Hud & 1339 & 3 & 197 & 15 & 1100 & 1 & 240 & 22 \\
\hline Endokrin & 498 & 1 & 195 & 39 & 961 & 1 & 251 & 26 \\
\hline Urinveier & 325 & 1 & 75 & 23 & 325 & 0 & 66 & 20 \\
\hline Kjønnsorganer & 272 & 1 & 58 & 21 & 2185 & 3 & 495 & 23 \\
\hline Sosialt & 28 & 0 & 3 & 11 & 40 & 0 & 4 & 10 \\
\hline Allment & 1037 & 2 & 185 & 18 & 1517 & 2 & 279 & 18 \\
\hline Blodsykdom & 261 & 1 & 85 & 33 & 343 & 0 & 94 & 27 \\
\hline Fordøyelse & 1992 & 4 & 326 & 16 & 2139 & 3 & 409 & 19 \\
\hline Øyne & 323 & 1 & 72 & 22 & 253 & 0 & 82 & 32 \\
\hline Ører & 293 & 1 & 89 & 30 & 411 & 1 & 137 & 33 \\
\hline Svangerskapsrelatert & & & & & 10296 & 13 & 108 & 1 \\
\hline Alle & 47073 & 100 & 10364 & 22 & 76379 & 100 & 15664 & 21 \\
\hline Alle, ekskl. svangerskap & 47073 & 100 & 10364 & 22 & 66083 & & 15556 & 24 \\
\hline
\end{tabular}

sosiodemografiske faktorer ble brukt som kategoriske variabler og relativ risiko (hasardrate) for innvilget uførepensjon ble estimert for kjønn og andre forklaringsvariabler.

Først ble hasardraten (HR) med 95\% konfidensintervall $(95 \% \mathrm{KI})$ for kvinner estimert i totalkohorten med "mann" som referansekategori justert bare for alder (modell 1). Deretter ble inntekt og utdannelse introdusert (modell 2 og modell 3), og til slutt en "full modell" som også inkluderte ukentlig arbeidstid og familiestatus (omsorg for barn under 18 år). Dette er vist $i$ tabell 2.

For å utforske kjønnforskjellene videre gjorde vi en analyse stratifisert for kjønn (tabell 3) for å se om noen av variablene har ulik effekt på kvinner og menn. Her er det to modeller, en med og en uten justering for diagnosegruppe hvor muskelskjelett er referansegruppe.

Tabell 4 viser relativ uførerisiko (HR) for kvinner, justert for alle andre forklaringsvariabler, for de 4 diagnosegruppene. Mann er fortsatt referansekategori. Øverste linje viser resultat for hele landet, deretter vises resultater for hvert fylke.

\section{RESULTATER}

Etter fem års oppfølging var den ujusterte uførefrekvensen $24 \%$ for kvinner og $22 \%$ for menn. Ujustert uførefrekvens økte med alder, lav utdannelse og lav inntekt. Gjennomsnittelig alder var nesten identisk i de kvinnelige og mannlige utvalgene, 40,4 mot 40,9 år. Gjennomsnittlig utdanningsnivå var litt høyere for kvinnene (11,7 år mot 11,3 år for menn). Gjennomsnittlig årsinntekt i 1996 var 215000 NOK for menn mot 162000 for kvinner.
Når hele studiepopulasjonen ble analysert (tabell 2), var HR relatert til "kvinne" 1.10 (95\% KI 1,08-1,13) justert bare for alder (modell 1). Når årsinntekt ble tatt inn i modellen (modell 2), skiftet HR fortegn til 0,93, (95\% KI 0,90-0,95) altså var risiko for uførepensjonering lavere for kvinner. Dette var tilfelle også når utdannelse ble inkludert: HR 0,95 (95\% KI 0,93-0,98). I en "full modell" som også inkluderte ukentlig arbeidstid og familiestatus, ble HR 0,99 (95\% KI 0,96-1,02), dvs. ingen kjønnsforskjell.

For å forklare (manglende) kjønnseffekt ble menn og kvinner analysert hver for seg, i to modeller, uten og med justering for diagnosefordeling (tabell 3). Risiko for uførepensjonering økte kraftig og lineært for begge kjønn ved økende alder og noe sterkere for menn. Menn og kvinner med 13-15 års utdanning hadde ikke høyere risiko en de med mer enn 15 års utdannelse. Deltakere med 10-12 års utdanning og de med bare grunnskole hadde signifikant høyere HR enn de to høyeste kategoriene for begge kjønn. For menn var det lik HR for de to laveste utdannelseskategoriene. Uførerisiko for alle inntektsgruppene under 275000 (referansegruppe) var høyere for begge kjønn. Dessuten var det øket uførerisiko blant deltidsarbeidende og tidligere arbeidsledige, med høyere HR blant menn som ikke hadde fulltidsarbeid. De med omsorgsoppgaver hadde lavere uførerisiko blant begge kjønn. Ved ytterligere justering for ulik fordeling på uføreårsak, var det mindre endringer av HR relatert til øvrige variabler.

Blant menn var det større forskjeller på uførerisiko mellom diagnosegruppene (modell 2). Med muskelskjelett som referanse var HR for psykisk 1,36, hjerte/ lunge 1,77 og "øvrige" 1,22. Respektive verdier for 
Tabell 2. Kvinners relative risiko for overgang til uførepensjon 5 år etter langtidssykmelding i 1997. N=47073 menn og 66083 kvinner (kvinner med svangerskapsdiagnoser ekskludert). Relativ risiko angitt med hasardrate (HR) med 95\% konfidensintervall (KI).

\begin{tabular}{|c|c|c|c|c|c|c|c|c|c|c|c|c|}
\hline & $\mathrm{HR}^{*}$ & $95 \%$ & KI & $\mathrm{HR}^{* *}$ & $95 \%$ & $\mathrm{KI}$ & $\mathrm{HR}^{* * *}$ & $95 \%$ & $\mathrm{KI}$ & $\mathrm{HR}^{* * * *}$ & $95 \%$ & KI \\
\hline Kvinne (ref mann) & 1,10 & 1,08 & 1,13 & 0,93 & 0,90 & 0,95 & 0,95 & 0,93 & 0,98 & 0,99 & 0,96 & 1,02 \\
\hline Alder Ref <40 år & 1,00 & & & 1,00 & & & 1,00 & & & 1,00 & & \\
\hline 40-49 år & 3,21 & 3,09 & 3,35 & 3,48 & 3,34 & 3,62 & 3,33 & 3,20 & 3,47 & 3,64 & 3,50 & 3,80 \\
\hline $50-59$ år & 7,34 & 7,07 & 7,61 & 8,05 & 7,76 & 8,36 & 7,49 & 7,21 & 7,79 & 7,66 & 7,35 & 7,98 \\
\hline $60-62$ år & 11,26 & 10,70 & 11,86 & 12,16 & 11,55 & 12,80 & 11,17 & 10,59 & 11,78 & 10,45 & 9,89 & 11,04 \\
\hline Inntekt Ref $>275000$ & & & & 1,00 & & & 1,00 & & & 1,00 & & \\
\hline 0-124 999 & & & & 2,12 & 2,02 & 2,23 & 1,86 & 1,76 & 1,96 & 1,16 & 1,10 & 1,23 \\
\hline $125000-199999$ & & & & 1,80 & 1,72 & 1,89 & 1,60 & 1,53 & 1,69 & 1,34 & 1,28 & 1,41 \\
\hline $200000-274999$ & & & & 1,42 & 1,36 & 1,49 & 1,35 & 1,28 & 1,41 & 1,29 & 1,24 & 1,36 \\
\hline Utdanning Ref $>15$ år & & & & & & & 1,00 & & & 1,00 & & \\
\hline 7-9 år & & & & & & & 1,49 & 1,41 & 1,57 & 1,47 & 1,39 & 1,55 \\
\hline 10-12 år & & & & & & & 1,32 & 1,26 & 1,39 & 1,30 & 1,24 & 1,37 \\
\hline 13-15 år & & & & & & & 1,07 & 1,02 & 1,13 & 1,06 & 1,00 & 1,12 \\
\hline \multicolumn{13}{|l|}{ Arb tid Ref full tid } \\
\hline 1-19 t/uke & & & & & & & & & & 1,95 & 1,86 & 2,03 \\
\hline 20-29 t/uke & & & & & & & & & & 1,22 & 1,16 & 1,27 \\
\hline Ukjent/arb ledig & & & & & & & & & & 2,84 & 2,76 & 2,93 \\
\hline Omsorg Ref har barn $<$ & & & & & & & & & & 1.00 & & \\
\hline Ikke barn & & & & & & & & & & 1,25 & 1,21 & 1,29 \\
\hline
\end{tabular}

$\mathrm{HR}^{*}$ justert for alder $\mathrm{HR}^{* *}$ justert for do.+inntekt $\mathrm{HR}^{* * *}$ justert for do.+utdanning HR**** Justert for do.+ ukentlig arb tid og omsorg for barn.

Tabell 3. Risiko for overgang til uførepensjon 5 år etter langtidssykmelding i 1997, separat for kvinner (N=66 083) og menn $(\mathrm{N}=47$ 073). Hasardrate (HR) med 95\% konfidensintervall (KI) for alder, inntekt, utdanningsnivå, arbeidstid og familiestatus (modell 1) og do+diagnosegruppe (modell 2).

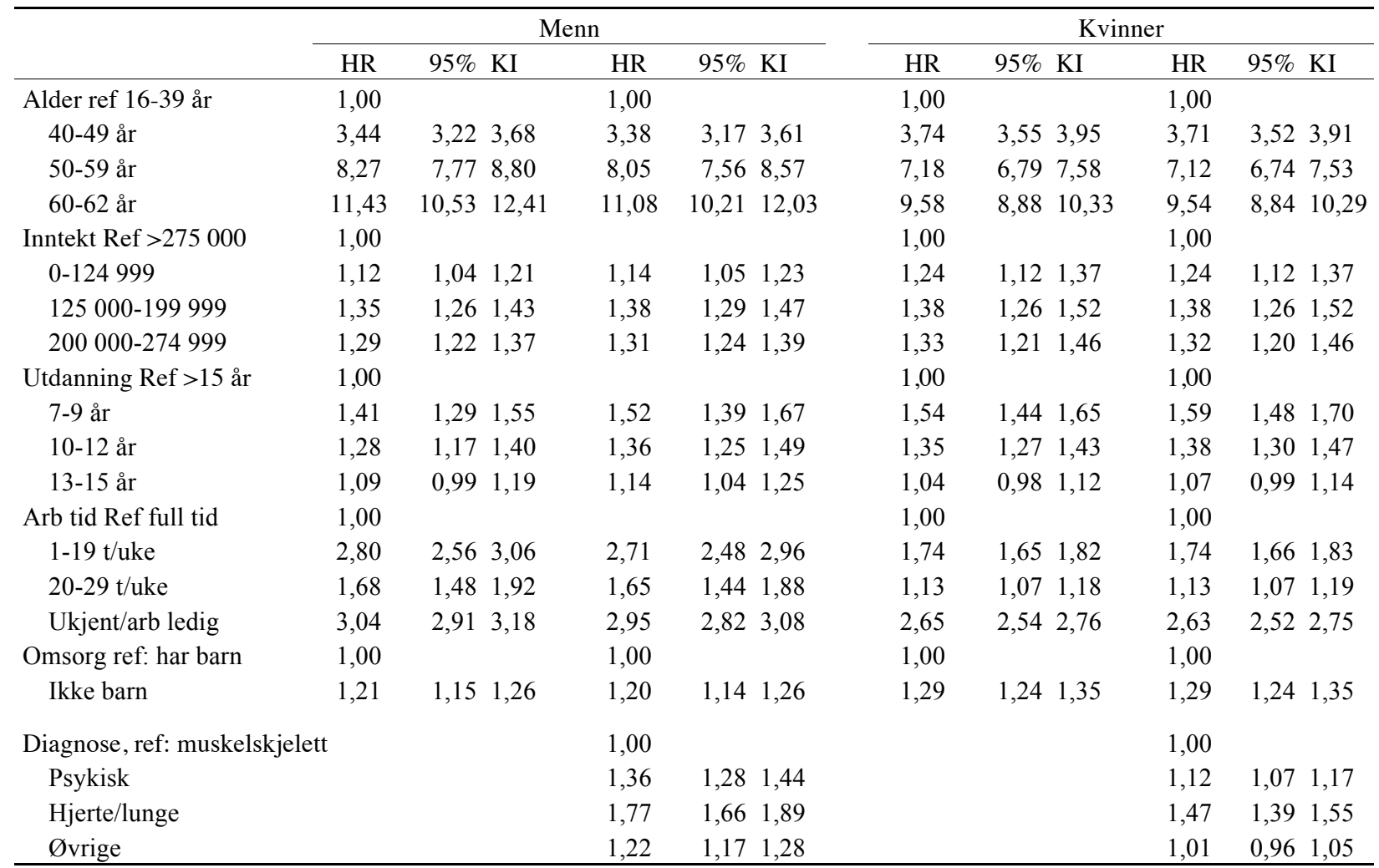


Tabell 4. Overgang i \% fra langtidssykmelding til uførepensjon (UFP) i de største diagnosegruppene, og relativ risiko for kvinner (ref mann) $\mathrm{i}$ hele landet og $\mathrm{i}$ hvert bostedsfylke. Relativ risiko estimert med hasardraten (HR) med $95 \%$ konfidensintervall $(95 \% \mathrm{KI})$ korrigert for alder, utdanning, inntekt, sysselsettingsstatus og familiesituasjon.

\begin{tabular}{|c|c|c|c|c|c|c|c|c|c|c|c|c|c|c|c|}
\hline \multirow[b]{2}{*}{ Bostedsfylke } & \multicolumn{4}{|c|}{ Muskel/skjelett } & \multicolumn{4}{|c|}{ Psykisk } & \multicolumn{4}{|c|}{ Hjerte/lunge } & \multicolumn{3}{|c|}{ Andre } \\
\hline & UFP $\%$ & HR & $95 \%$ & $\mathrm{KI}$ & UFP \% & HR & $95 \%$ & $\mathrm{KI}$ & UFP\% & HR & $95 \%$ & $\mathrm{KI}$ & UFP\% & HR & $95 \% \mathrm{KI}$ \\
\hline Hele landet & 20,3 & 1,13 & 1,08 & 1,17 & 24,4 & $\mathbf{0 , 8 8}$ & $\mathbf{0 , 8 3}$ & 0,94 & 32,4 & 0,96 & 0,87 & 1,05 & 26,1 & 0,90 & $\mathbf{0 , 8 4} \quad 0,95$ \\
\hline Oslo & 17,8 & 1,14 & 0,99 & 1,30 & 21,5 & 0,81 & 0,67 & 0,99 & 29,6 & 1,01 & 0,78 & 1,32 & 24,6 & 0,59 & $\mathbf{0 , 4 8} \quad \mathbf{0 , 7 2}$ \\
\hline Akershus & 18,6 & 1,26 & 1,10 & 1,44 & 21,9 & 0,99 & 0,79 & 1,24 & 28,1 & 1,12 & 0,83 & 1,50 & 23,9 & 0,75 & $0,60 \quad 0,94$ \\
\hline Østfold & 19,8 & 1,14 & 0,96 & 1,35 & 24,9 & 1,06 & 0,81 & 1,40 & 30,5 & 0,98 & 0,69 & 1,39 & 25,6 & 0,78 & $0,591,03$ \\
\hline Hedmark & 22,7 & 1,23 & 1,04 & 1,45 & 23,6 & 0,71 & $\mathbf{0 , 5 1}$ & 0,97 & 33,3 & 1,18 & 0,78 & 1,78 & 26,2 & 0,79 & $0,581,08$ \\
\hline Oppland & 20,9 & 0,96 & 0,80 & 1,14 & 23,5 & 0,90 & 0,66 & 1,22 & 30,4 & 1,00 & 0,66 & 1,53 & 24,7 & 0,86 & $0,62 \quad 1,19$ \\
\hline Buskerud & 15,6 & 1,07 & 0,89 & 1,30 & 21,6 & 1,09 & 0,82 & 1,45 & 29,0 & 1,08 & 0,73 & 1,60 & 25,5 & 0,47 & $\mathbf{0 , 3 5} \quad \mathbf{0 , 6 3}$ \\
\hline Vestfold & 23,8 & 1,39 & 1,16 & 1,67 & 28,5 & 0,99 & 0,75 & 1,31 & 32,9 & 0,93 & 0,59 & 1,45 & 29,9 & 0,66 & $\begin{array}{ll}0,48 & 0,90\end{array}$ \\
\hline Telemark & 22,2 & 1,35 & 1,10 & 1,65 & 26,4 & 1,01 & 0,74 & 1,39 & 33,5 & 0,97 & 0,61 & 1,56 & 26,9 & 0,65 & $0,47 \quad 0,90$ \\
\hline Aust-Agder & 24,2 & 1,12 & 0,88 & 1,44 & 27,6 & 1,00 & 0,71 & 1,41 & 37,3 & 0,67 & 0,39 & 1,14 & 24,2 & 0,35 & $0,23 \quad 0,55$ \\
\hline Vest-Agder & 24,2 & 1,04 & 0,84 & 1,28 & 23,9 & 0,85 & 0,62 & 1,18 & 37,3 & 1,18 & 0,76 & 1,82 & 27,1 & 0,57 & $\begin{array}{ll}0,39 & 0,85\end{array}$ \\
\hline Rogaland & 20,5 & 1,26 & 1,06 & 1,50 & 28,6 & 0,70 & 0,56 & $\mathbf{0 , 8 8}$ & 35,1 & 1,15 & 0,78 & 1,71 & 27,3 & 0,45 & $0,330,60$ \\
\hline Hordaland & 20,0 & 1,05 & 0,91 & 1,21 & 26,6 & 0,91 & 0,75 & 1,12 & 31,0 & 0,85 & 0,61 & 1,18 & 25,2 & 0,50 & $0,40 \quad 0,63$ \\
\hline Sogn og Fjordane & 20,7 & 1,17 & 0,89 & 1,54 & 22,2 & 0,84 & 0,51 & 1,39 & 39,4 & 0,81 & 0,45 & 1,47 & 21,5 & 0,97 & $0,551,71$ \\
\hline Møre og Romsdal & 18,4 & 1,13 & 0,93 & 1,38 & 23,4 & 1,02 & 0,74 & 1,41 & 32,3 & 0,88 & 0,59 & 1,32 & 25,5 & 0,73 & $0,53 \quad 1,00$ \\
\hline Sør-Trøndelag & 17,9 & 1,14 & 0,96 & 1,37 & 21,5 & 0,79 & 0,60 & 1,05 & 31,3 & 0,84 & 0,57 & 1,22 & 27,8 & 0,81 & $0,631,06$ \\
\hline Nord-Trøndelag & 21,9 & 1,04 & 0,82 & 1,34 & 25,8 & 0,98 & 0,65 & 1,48 & 40,3 & 0,63 & 0,35 & 1,11 & 27,1 & 0,90 & $0,591,38$ \\
\hline Nordland & 24,5 & 1,27 & 1,09 & 1,49 & 25,3 & 1,29 & 0,95 & 1,76 & 36,3 & 0,92 & 0,60 & 1,40 & 29,1 & 0,81 & $0,621,06$ \\
\hline Troms & 20,5 & 1,19 & 0,97 & 1,45 & 21,1 & 0,69 & 0,44 & 1,07 & 38,4 & 0,74 & 0,45 & 1,20 & 29,9 & 0,88 & $0,65 \quad 1,20$ \\
\hline Finnmark & 20,5 & 1,44 & $\mathbf{1 , 0 8}$ & 1,93 & 29,4 & 0,98 & 0,56 & 1,74 & 36,0 & 2,02 & 0,98 & 4,16 & 27,4 & 0,88 & $0,57 \quad 1,35$ \\
\hline
\end{tabular}

kvinner var $1,12,1,47$ og 1,01 .

Tabell 4 viser diagnosespesifikke analyser. Landsgjennomsnittet for uførepensjonering ved MSP er $20,3 \%$ og ved psykiske lidelser $24,4 \%$. Samlet for hele landet (øverste linje i tabellen) hadde kvinner med MSP signifikant høyere uførerisiko enn menn med MSP, justert for alder, inntekt, utdanningsnivå, arbeidstid og omsorg for barn: HR 1,13 (95\% KI 1,081,17). Ved psykisk lidelse var det lavere risiko for kvinner, HR 0,88 (95\% KI 0,83-0,94), og det samme ved "Øvrige" lidelser: HR 0,90 (95\% KI 0,84-0,95). Ved langtidssykmelding med hjerte/lunge diagnoser, var det ingen forskjell etter justering for de samme kovariater. De sosiodemografiske variablene hadde forventet effekt i alle diagnosegrupper, unntatt ved hjerte/lunge hvor utdanning ikke hadde noen effekt (ikke vist $\mathrm{i}$ tabell).

Uførerisiko i prosent og fullt justert HR relatert til kjønn (mann fortsatt referanse) i hvert fylke er også vist i tabell 4: I fylkene varierer uføreraten fra 15,6\%24,5\% ved MSP, 21,1\%-29,4\% ved psykisk lidelse, 21,5\%-29,1\% for "øvrige" og 28,1\%-39,4\% ved hjerte/ kar. Ved MSP var HR relatert til kvinner (fullt justert) forhøyet i syv fylker og ikke lavere i noen fylker. Dette betyr at det var høyere risiko for uførepensjon for kvinner med MSP sammenliknet med menn i disse fylkene. Ved psykiske lidelser var HR for kvinner lavere enn for menn i Oslo, Hedmark og Rogaland, og ingen fylker hadde høyere risiko for kvinner. Ved hjerte/ lungesykdom var det ingen signifikante forskjeller mellom fylkene. For "øvrige" var HR for "kvinne" sig- nifikant lavere i 10 fylker, og den laveste hasardraten var $0,35(0,23-0,55)$.

\section{DISKUSJON}

\section{Hovedfunn}

Fordeling av sykmeldinger relatert til kjønn og diagnosegrupper i denne studien samsvarer med fordeling $\mathrm{i}$ liknende studier, relatert til totalt fravær, psykisk lidelse og MSP. Startpunktet for studien var en 38,7\% høyere insidens av langtidssykmelding blant kvinner relatert til menn i 1997. Når man ser bort fra svangerskapsrelatert langtidssykmelding var forskjellen $28,7 \%$. Overgangsraten var $24 \%$ hos kvinner når $\mathrm{W}$ diagnoser (svangerskapsrelatert) ble ekskludert og $22 \%$ for menn. I alt ble 15664 kvinner og 10364 menn i kohorten uførepensjonert i oppfølgingstiden.

Justert for relevante kovariater, var det ingen kjønnseffekt på uførerisiko etter langtids sykefravær. Imidlertid var det øket risiko for kvinner ved MSP, lavere ved psykisk og "øvrige", og ingen forskjell ved hjerte/lunger. Dette viser at høyere sykefravær for kvinner bidrar til "the gender gap" i bruk av uførepensjon. Kjønnsforskjellen øker imidlertid ikke fram til tilkjent UFP, for eksempel på grunn av ulikt resultat av "oppfølging av langtidssykmeldte".

Andelen av de viktigste diagnosegruppene var forbausende lik blant kvinner og menn. Litt større andel av mennene hadde MSP (som har best prognose med tanke på å vende tilbake til arbeidslivet) og hjerte/kar (dårligst prognose). 
Tidligere påviste prediktorer for overgang fra langtidssykefravær til uførepensjon ble bekreftet, med unntak av inntekt, som ikke var lineær. Det var øket uførerisiko for de uten omsorg for barn og for de som ikke var i fullt arbeid både hos kvinner og menn, noe som indikerer at dobbelbyrdeeffekten ikke ble bekreftet.

Når menn og kvinner ble analysert separat, framkom beskjedne ulikheter i effekt av de sosiodemografiske variablene, dvs. liten interaksjon mellom kjønn og andre kovariater. Alderseffekten var imidlertid litt ulik, idet forskjellen i uførerisiko mellom de over og de under 50 år var større hos menn enn hos kvinner (sterkere alderseffekt). Dette er tidligere påvist i enda sterkere grad ved MSP (15).

Kjønnseffekten og uførefrekvensen varierte betydelig mellom fylkene, ulikt for hver diagnosegruppe. Det var liten kjønnsforskjell ved hjerte/lunge diagnoser, og størst variasjon for muskelskjelett og "øvrige".

\section{Studiens styrker}

Dette er en svært stor populasjonsbasert kohortstudie som er basert på objektive sosiodemografiske data fra pålitelige offentlige registre, hentet fra FD trygd. Sykefraværsdiagnosene er medisinsk verifisert av leger, og klassifisert ved hjelp av ICPC. Det er en lang oppfølgingsperiode, og ingen bortfall siden alle deltakere kunne følges til uførepensjonering, emigrasjon eller død.

\section{Begrensninger}

Registerbaserte studier har en del svakheter sammenliknet med klinisk baserte studier med få deltakere men med en rekke selvrapporterte og kliniske variabler. De store helseundersøkelser har også rikere datatilfang, både ved egenrapporter i standardiserte instrumenter og enkle medisinske undersøkelser. Postale surveys har også store utvalg, men disse metodene har problemer med deltakelsen og ulike former for skjevhet (bias), rapporteringsbias for eksempel.

Den foreliggende studien mangler data om arbeidsforhold, familieøkonomi og yrker. Data om ukentlig arbeidstid er også usikre pga dårlig kvalitet på arbeidstaker/arbeidsgiver registeret.

Som kjent økte sykefraværet betydelig fra 19932000, etter en kraftig nedgang fra 1987-1992 (65). 1997 var altså et år med middeles høyt fravær. I en tidligere nasjonal studie med baseline i 1990-1991 var årlig insidens av langtidssykmelding (sykmelding lengre enn 8 uker) $6,5 \%$ for kvinner og 4,9\% for menn (30). I 1997 var frekvens av langtidssykmelding økt til $8,4 \%$ for kvinner og $4,7 \%$ for menn (9), dvs. øket kjønnsforskjell. Tilgang til uførepensjon har også økt i denne perioden - jfr. fig 1. - og den var svært høy i 1999 og 2000, noe som også synes å samvariere med økt kjønnsforskjell blant de nye uføre.

I våre statistiske modeller, basert på Cox regresjon, er kovariater forutsatt å ha samme effekt for menn og kvinner. Modeller uten interaksjoner vil skjule kjønnsforskjeller i effekt av noen prediktorer for overgang til
UFP. Slike forskjeller fremkommer imidlertid i liten grad i de kjønnsstratifiserte analysene (tabell 3).

\section{Overgangsraten fra langtidssykmelding til uforepensjon - tidligere studier}

I en tidligere studie fra 1990-1994 basert på KIRUT data var 3-års risiko for overgang fra langtidssykmelding til uførepensjon 12,4\% for kvinner og 12,6\% for menn. I en studie med data fra Hordaland i 1994-1999, var overgangsraten under fem års oppfølging $27 \%$ for kvinner og 18\% for menn med MSP, og 25\% for kvinner og $31 \%$ for menn med psykiatriske diagnoser (9).

Generelt har kjønnsforskjeller (høyere insidens og høyere trygdeforbruk for kvinner) blitt forklart med en rekke, delvis motstridende teorier (32). Denne studien undersøkte betydningen av sosioøkonomiske og demografiske variabler $(15,16,20,30,31,37)$ og diagnoser (9) som forklaring på ulik risiko for uførepensjonering. Det er tidligere påvist høyere risiko for kvinner sykmeldt med MSP, men lavere ved psykiske diagnoser, og det samme ble funnet her. Vi fant ikke støtte for "dobbelbyrde teorien", omsorg for barn økte ikke risiko for uførepensjonering. Det var også høyere risiko for deltidsarbeidere. Tidligere påviste effekter av sosiodemografiske og diagnostiske variabler ble også bekreftet.

\section{Konklusjoner og behov for videre forskning (66)}

Det er påvist en stor kvinnelig overhyppighet i prevalens og sykefravær både med MSP og psykiske lidelser. Dette er også utgangspunket i denne studien. Høyere risiko for kronifisering hos kvinner har blitt funnet i tidligere studier ved MSP, og for menn ved psykiske lidelser. Studien bekreftet at "the gender gap" ved MSP kan forklares og "elimineres" i regresjonsmodeller som inkluderer sosiodemografiske variabler (37) og diagnosefordeling (15). Imidlertid er det mulig at andre resultater kan fremkomme ved bruk av interaksjonsledd. Videre arbeid med slike modeller er ønskelig. Det samme gjelder forskjeller mellom fylkene, som er et underordnet fokus i denne studien. Slike studier bør ha en prospektiv, multilevel design (55).

Det pågår for tiden betydelig forskningsaktivitet i mange land vedrørende risikofaktorer for permanent uførhet etter sykefravær, særlig relatert til MSP (64). Man bør inkludere kjønnseffekten i denne sammenheng, primært ved hjelp av kjønnsspesifikke analyser. Rehabiliteringsprogrammer for sykmeldte bør sannsynligvis ha kjønnsspesifikk og diagnosespesifikk design.

Alle data ble utlevert fra SSB, men forfatteren er ansvarlig for analysene.

Studien er godkjent av Datatilsynet.

John Gunnar Mceland og Espen Bratberg har deltatt i flere studier som artikkelen er basert på.

Artikkelen er delvis finansiert av Norges Forskningsråd gjennom Helseøkonomi Bergen. 


\section{REFERANSER}

1. Clausen B. Restricting the influx of disability beneficiaries by means of law: experiences in Norway. Scand $J$ Soc Med 1998; 26: 1-7.

2. Lund E. Uførepensjon i Norge 1977-87. Tidsskr Nor Lageforen 1990; 110: 1387-9.

3. Uførepensjon NOU 1990: 17, Oslo: 1990.

4. Trygdestatiske årbøker 1997-2003. Oslo: Rikstrygdeverket.

5. Sykefravær og uførepensjonering: Et inkluderende arbeidsliv. NOU 2000: 27. Oslo: 2003.

6. Gjesdal S. From long-term sickness absence to disability pension. Dr. avhandling. Institutt for Samfunnsmedisinske fag, Universitet i Bergen, 2003.

7. Brenner $\mathrm{H}$, Ahern W. Sickness absence and early retirement on health grounds in the construction industry in Ireland. Occup Environ Med 2000; 57: 615-20.

8. Kivimaki M, Forma P, Wikstrom J, Halmeenmaki T, Pentti J, Elovainio M, et al. Sickness absence as a risk marker of future disability pension: the 10-town study. J Epidemiol Community Health 2004; 587: 10-1.

9. Gjesdal S, Ringdal PR, Haug K, Maeland JG. Predictors of disability pension in long-term sickness absence: results from a population-based and prospective study in Norway 1994-1999. Eur J Public Health 2004; 14: $398-405$

10. Karlsson NE, Carstensen JM, Gjesdal S, Alexanderson KA. Risk factors for disability pension in a population-based cohort of men and women on long-term sick leave in Sweden. Eur J Public Health 2008; 18: $224-31$

11. Krause N, Lynch J, Kaplan GA, Cohen RD, Goldberg DE, Salonen JT. Predictors of disability retirement. Scand J Work Environ Health 1997; 23: 403-13.

12. Mansson NO, Rastam L. Self-rated health as a predictor of disability pension and death - a prospective study of middle-aged men. Scand J Public Health 2001; 29: 151-8.

13. Upmark M, Lundberg I, Sadigh J, Allebeck P, Bigert C. Psychosocial characteristics in young men as predictors of early disability pension with a psychiatric diagnosis. Soc Psychiatry Psychiatr Epidemiol 1999; 34: $533-40$.

14. Biering-Sorensen F, Lund J, Hoydalsmo OJ, Darre EM, Kryger P, et al. Risk indicators of disability pension. A 15 year follow-up study. Dan Med Bull 1999; 46: 258-6.

15. Gjesdal S, Bratberg E, Mæland JG. Musculoskeletal impairments in the Norwegian working population: the prognostic role of diagnoses and socioeconomic status: a prospective study of sickness absence and transition to disability pension. Spine 2009; 34: 1519-25.

16. Abansolo L, Carmona L, Lajas C, Candelas G, Blanco M, Loza E, et al. Prognostic factors in short-term disability due to musculoskeletal disorders. Arthritis Rheum 2008; 59: 489-96.

17. Pincus T, Burton AK, Vogel S, Field AP. A systematic review of psychological factors as predictors of chronicity/disability in cohorts of low back pain. Spine 2002; 27: 109-20.

18. Linton SJ, Gross D, Schultz IZ, Main C, Cote P, Pransky G, et al. Prognosis and the identification of workers risking disability: research issues and directions for future research. J Occup Rehabil 2005; 15: 459-74.

19. Lotters F, Burdorf A. Prognostic factors for duration of sickness absence due to musculoskeletal disorders. Clin J Pain 2006; 22: 212-221.

20. Mansson NO, Rastam L, Eriksson KF, Israelsson B. Socioeconomic inequalities and disability pension in middle-aged men. Int J Epidemiol 1998; 27: 1019-25.

21. Krokstad S, Johnsen R, Westin S. Social determinants of disability pension: a 10-year follow-up of 62000 people in a Norwegian county population. Int J Epidemiol 2002; 31: 1183-91.

22. Hagen KB, Holte HH, Tambs K, Bjerkedal T. Socioeconomic factors and disability retirement from back pain: a 1983-1993 population-based prospective study in Norway. Spine 2000; 25: 2480-7.

23. Holte HH, Tambs K, Bjerkedal T. Manual work as predictor for disability pensioning with osteoarthritis among the employed in Norway 1971-1990. Int J Epidemiol 2000; 29: 487-94.

24. Gjesdal S. Sykefraværets utvikling i Norge 1975-2002. Tidskr Nor Lageforen 2005; 125: 742-5.

25. Leijon M, Hensing G, Alexanderson K. Gender trends in sick-listing with musculoskeletal symptoms in a Swedish county during a period of rapid increase in sickness absence. Scand J Soc Med 1998; 26: 204-13.

26. Hansson T, Jensen I. Swedish Council on Technology Assessment in Health Care (SBU). Chapter 6. Sickness absence due to back and neck disorders. Scand J Public Health Suppl 2004; 63: 109-51.

27. Natvig B, Nessioy I, Bruusgaard D, Rutle O. [Musculoskeletal complaints in a population. Occurrence and localization]. Tidsskr Nor Lageforen 1994; 114: 323-7.

28. Wijnhoven HA, de Vet HC, Picavet HS. Prevalence of musculoskeletal disorders is systematically higher in women than in men. Clin J Pain 2006; 22: 717-24. 
29. Laaksonen M, Martikainen P, Rahkonen O, Lahelma E. Explanations for gender differences in sickness absence: evidence from middle-aged municipal employees from Finland. Occup Environ Med 2008; 65: $325-$ 30 .

30. Gjesdal S, Bratberg E. The role of gender in long-term sickness absence and transition to permanent disability benefits. Results from a multiregister based, prospective study in Norway 1990-1995. Eur J Public Health 2002; 12: 180-6.

31. Claussen, B, Dalgard OS. Disability pensioning: The gender divide can be explained by occupation, income, mental distress and health. Scand J Public Health 2009; 37: 590-7.

32. Wijnhoven HA, de Vet HC, Picavet HS. Explaining sex differences in chronic musculoskeletal pain in a general population. Pain 2006; 124: 158-66.

33. Diderichson F. Kvinnors sjukfrånvaro: Arbetsmiljön orsak til kraftig ökning. Läkartidningen 1993; 90: 28992.

34. Hooftman WE, van Poppel MN, van der Beek AJ, Bongers PM, van Mechelen W. Gender differences in the relations between work-related physical and psychosocial risk factors and musculoskeletal complaints. Scand $J$ Work Environ Health 2004; 30: 261-78.

35. Fillingim RB. Sex, gender, and pain: women and men really are different. Curr Rev Pain 2000; 4: 24-30.

36. Tosi LL, Boyan BD, Boskey AL. Does sex matter in musculoskeletal health? The influence of sex and gender on musculoskeletal health. J Bone Joint Surg Am 2005; 87: 1631-47.

37. Brage S, Nygard JF, Tellnes G. The gender gap in musculoskeletal-related long-term sickness absence in Norway. Scand J Soc Med 1998; 26: 34-43.

38. Barsky AJ, Peekna HM, Borus JF. Somatic symptom reporting in women and men. J Gen Intern Med 2001; 16: $266-75$.

39. Kessler RC, Ormel J, Demler O, Stang PE. Co-morbid mental disorders account for the role impairment of commonly occurring chronic physical disorders: results from the National Comorbidity Survey. J Occup Environ Med 2003; 45: 1257-66

40. Hensing G, Spak F. Psychiatric disorders as a factor in sick-leave due to other diagnoses. A general population-based study. Br J Psychiatry 1998; 172: 250-6.

41. Piccinelli M, Wilkinson G. Gender differences in depression. Critical review. Br J Psychiatry 2000; 177: 48692.

42. Artazcoz L, Artieda L, Borrell C, Cortes I, Benach J, Garcia V. Combining job and family demands and being healthy: what are the differences between men and women? Eur J Public Health 2004; 14: 43-8.

43. Vaananen A, Kevin MV, Ala-Mursula L, Pentti J, Kivimaki M, Vahtera J. The double burden of and negative spillover between paid and domestic work: associations with health among men and women. Women Health 2004; 40: 1-18.

44. Mastekaasa A. Parenthood, gender and sickness absence. Soc Sci Med 2000; 50: 1827-42.

45. Bratberg E, Dahl S, Risa A. Do combinations of Career and Family Obligations Increase Sickness Absence among Women? Eur Sociol Rev 2002; 18: 233-49.

46. Moncrieff J, Pomerleau J. Trends in sickness benefits in Great Britain and the contribution of mental disorders. J Public Health Med 2000; 22: 59-67.

47. Gjesdal S, Ringdal PR, Haug K, Mæland JG. Long-term sickness absence and disability pension with psychiatric diagnoses: a population-based cohort study Nord J Psychiatry 2008; 62: 294-30

48. Nystuen P, Hagen KB, Herrin J. Mental health problems as a cause of long-term sick leave in the Norwegian workforce. Scand J Public Health 2001; 29: 175-182.

49. Mykletun A, Overland S, Glozier N. Is the impact of mental health problems on disability pension award underestimated? Eur J Public Health 2005; 15: 80-81.

50. Jarvisalo J, Andersson B, Boedeker W, Houtman I. Mental Disorders as a Major Challenge in Prevention of Work Disability. Experiences in Finland, Germany, the Netherlands and Sweden Helsinki: FPA; 2005.

51. Kringlen E, Torgersen S, Cramer V. A Norwegian psychiatric epidemiological study. Am J Psychiatry 2001; 158: $1091-8$.

52. Stordal E, Bjartveit Kruger M, Dahl NH, Kruger O, Mykletun A, Dahl AA. Depression in relation to age and gender in the general population: the Nord-Trondelag Health Study (HUNT). Acta Psychiatr Scand 2001; 104: 210-6.

53. Hensing G, Alexanderson K, Allebeck P, Bjurulf P. Sick-leave due to psychiatric disorder: higher incidence among women and longer duration for men. Br J Psychiatry 1996; 169: 740-6.

54. Hensing G, Brage S, Nygard JF, Sandanger I, Tellnes G. Sickness absence with psychiatric disorders - an increased risk for marginalisation among men? Soc Psychiatry Psychiatr Epidemiol 2000; 35: 335-40.

55. Bratberg E, Gjesdal S, Mæland JG. Sickness absence with psychiatric diagnoses: individual and contextual predictors of permanent disability. Health Place 2009; 15: 308-14 
56. Geografisk variasjon i tilgang av nye uførepensjonister 1980-1997 etter fylke. Rapport 6/ 2000. Rikstrygdeverket, Oslo.

57. Rege M, Telle K, Votruba M. Social interaction effects in disability pension participation. Oslo, Statistics Norway, DP No 4962007.

58. Krokstad S, Magnus P, Skrindal A, Westin S. The importance of social characteristics of communities for the medically based disability pension. Eur J Public Health 2004; 14: 406.

59. Bambra C, Norman P. What is the association between sickness absence, mortality and morbidity? Health Place 2006; 12: 728-733

60. Weich S, Lewis G. Poverty, unemployment, and common mental disorders: population based cohort study. BMJ 1998; 317: 115-9.

61. Fone D, Dunstan F, Lloyd K, Williams G, Watkins J, Palmer S. Does social cohesion modify the association between area income deprivation and mental health? A multilevel analysis. Int J Epidemiol 2007; 36: 338-45.

62. Brage S, Bentsen BG, Bjerkedal T, Nygard JF, Tellnes G. ICPC as a standard classification in Norway. Fam Pract 1996; 13: 391-6

63. Hofmans-Okkes IM, Lamberts H. The International Classification of Primary Care (ICPC): new applications in research and computer-based patient records in family practice. Fam Pract 1996; 13: 294-302.

64. Altman, DG. Practical Statistics for Medical Research. Chapman \& Hill, London, 1991.

65. Gjesdal S. Sykefraværets utvikling i Norge 1975-2002. Tidsskr Nor Loegeforen 2005; 125: 742-5.

66. Alexanderson K, Hensing G. More and better research needed on sickness absence. Scand J Public Health 2004; 32: 321-3. 